\title{
Sustainable Dairy Industry by Using Renewable Energy Source
}

\author{
Seda Genç ${ }^{1 *}$, Nurdan Yıldırım² \\ ${ }^{1}$ Yasar University, Vocational School, Food Processing Department, 35100, Bornova, Izmir, TR, +90 2325708251 \\ 2 Yasar University, Engineering Faculty, Energy Systems Engineering, 35100, Bornova, Izmir, TR, +90 2325708636 \\ *seda.genc@yasar.edu.tr, nurdan.yildirim@yasar.edu.tr \\ *Corresponding Author \\ Received: 8 February 2017 \\ Accepted: 22 May 2017 \\ DOI: 10.18466/cbayarfbe.339326
}

\begin{abstract}
Renewable energy system is a crucial issue for sustainable development. Thermodynamic analysis, especially exergy analysis plays an important role to evaluate sustainability of the industrial processing systems. Food production industry is one of the energy consuming sectors and dairy industry could be placed at one of the top substantial amount of energy consuming food industry segments. Hence, in this study, thermodynamic analysis of a milk pasteurization system assisted by a renewable energy resource -geothermal energy was investigated. In this regard, for the pasteurization of $1 \mathrm{~kg} / \mathrm{s} \mathrm{milk} \mathrm{at} 76^{\circ} \mathrm{C}$ the required pasteurization capacity was $21.88 \mathrm{~kW}$. In case of using geothermal fluid at $100^{\circ} \mathrm{C}$ the exergetic efficiency of the whole system was computed $71.05 \%$ as the first law efficiency and $56.81 \%$ as second law efficiency, respectively. According to the exergy analysis the biggest exergy destruction rate was seen in the absorber as $4.577 \mathrm{~kW}$. Additionally, in order to develop the system' efficiency the optimum operating conditions of the system components were determined such as absorber, condenser, evaporator, heat exchanger.
\end{abstract}

Keywords - Energy, Exergy, Geothermal Energy, Milk Pasteurization, Optimization

\section{Introduction}

One of the essential component of healthy and balanced diet is milk which is consumed by more than 6 billion people. According to Food and Agricultural Organization statistics the global dairy production reached to 703,996,079 metric tons [1]. For this reason, pasteurization is a critical step in the processing of milk.

Dairy industry is accepted as one of the most energy intensive industry. Turkey is globally in top ten countries with the number of the milk processing facilities with a number of which is 1,250,947 [2]. In dairy industry, heating and cooling are the most used and energy intensive processes. Although it might changes due to processing system in a dairy facility the most used heat treatment is the pasteurization which is done between $60-75^{\circ} \mathrm{C}$. The heat necessary for the pasteurization operation is provided by energy carriers such as natural gas, coal and electricity.

As the global need to the energy increases day by day, unfortunately the fossil energy resources decreases dramatically. For this reason, the demand for the renewable energy rises rapidly. Turkey is one of the richest country in terms of geothermal resources which is widely accepted as renewable energy. Geothermal energy is not only used in power generating, but also used in industrial process and domestic heating and cooling. Geothermal energy is mostly preferred since it is an environmentally friendly, economic and sustainable source [3,4]. In this sense, geothermal energy could be used in the milk pasteurization process as well.

The energy analysis of the systems is conducted according to the first law of thermodynamics, known as conservation of energy. Unfortunately, first law analysis does not give any information related to energy quality and irreversibility within the system. Exergy analysis which is an analysis of the second law of thermodynamics is one of the effective tools used to measure the systems' performances [5]. By defining the irreversibility within the system through exergy analysis could help to improve and increase the system performance.

There are various researches in common literature related to energy and exergy analysis of milk and dairy processing stages. Quijera and Labidi [6] used exergy analysis to compare two different systems to see whether integration of the thermos solar technology in a dairy process would be used to support fossil fuels. Electricity and natural gas are used as energy carrier within the first system. Natural gas and sun energy is used within the second system. In comparison of the first and second systems, the exergy efficiencies were 
found as $10.3 \%$ and between 5.2 and $14.3 \%$. The variation in the second system efficiency results is depending on the solar fractions. In another research, Soufiyan et al. [7] conducted an exergy analysis of a milk processing plant and found that the largest exergy destruction rate with the value of $12695.34 \mathrm{~kW}$ occurred in the compressor and boiler combination of the steam generation system. Yildirım and Genc [8] studied thermodynamic analysis of a milk pasteurization process consists of a cooling section equipped with vapor absorption refrigeration cycle assisted by geothermal energy. This thermodynamic analysis was conducted both for each component and whole system. Total exergy destruction rate of the whole system was calculated as $13.66 \mathrm{~kW}$ and it was found that $51.07 \%$ of this value resulted from the absorption cooling system. And these results indicate to focus on VAC system not only component based but also as a whole to obtain higher exergetic efficiencies.

The aim of this study is to find the optimum operating conditions in order to increase exergy efficiency through studying the thermodynamic optimization of the milk pasteurization system assisted by geothermal energy.

\section{Mathematical Model}

\subsection{System Description}

Figure 1 illustrates a schematic diagram of the considered system of a milk pasteurization system assisted by geothermal energy. In this regard, all energy required for pasteurized milk production was supplied by a system where a geothermal fluid was used in an absorption refrigeration cycle consists of ammonia-water mixture.

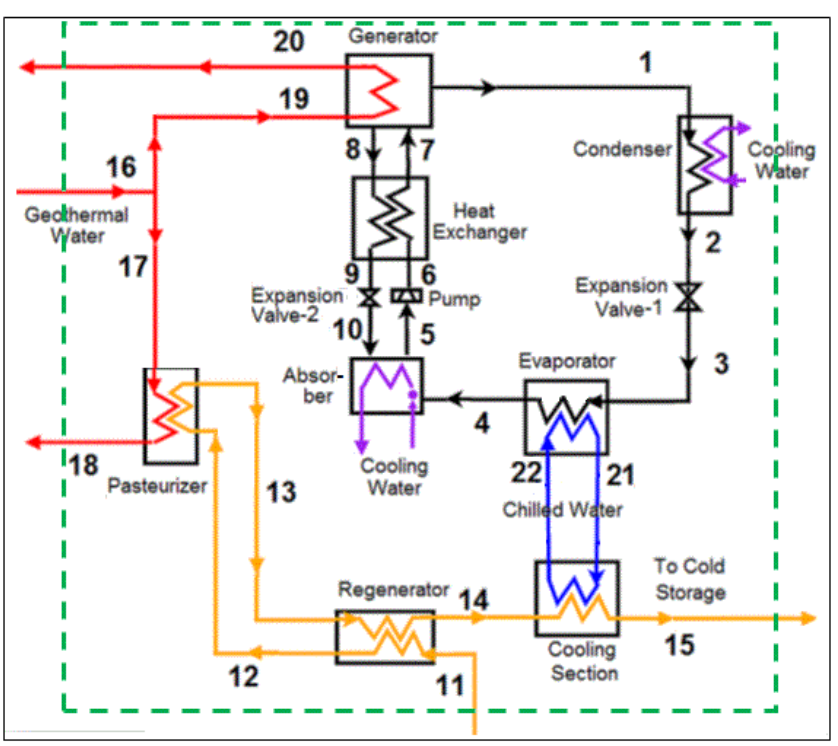

Figure 1. Schematic diagram of the milk pasteurization system assisted by geothermal energy [8].
The system basically consists of (i) the cooling system (for obtaining of heat for the pasteurization as well as cooling of milk), respectively (ii) regenerator (preheating and precooling of milk), (iii) the pasteurizer and (iv) the cooling unit (for cooling pasteurized milk). In this system, the geothermal fluid is divided in two streams called as stream 17 and 19. The first one (stream 17) goes to the pasteurizer and provides heat for pasteurization process (stream 13) and stream 19 run to the absorption cooling system where water and ammonia are used as an absorbent and a refrigerant, respectively. The absorption cooling system's components are the generator, the condenser, the evaporator, the absorber, the pump, two expansion valves and the heat exchanger.

The assumptions for the pasteurization system analysis are as follows:

(a) The whole system and its components are assumed to be run in steady state condition.

(b) Ammonia-water solutions are assumed to be in equilibrium in the generator and the absorber at their respective pressures and temperatures.

(c) The directions of heat transfer to the system and work transfer from the system are positive.

(d) The pressure and heat losses in the pipelines and the system components (generator, condenser, evaporator, absorber, regenerator, pasteurizer cooler, etc.) are ignored.

(e) All throttle valves are assumed to be operated under adiabatic condition, which results in constant enthalpy process.

(f) The generator temperature is considered as $5^{\circ} \mathrm{C}$ less than geothermal resource temperature.

(g) The milk temperature at the pasteurizer entrance is $2^{\circ} \mathrm{C}$ less than temperature of the geothermal resource.

(h) The cold storage temperature of the milk is assumed as $4^{\circ} \mathrm{C}$.

(i) The heat exchanger thermal efficiency is considered as 0.80 .

(j) The effectiveness of the regenerator is accepted as 0.95.

(k) Specific heat of the milk is kept constant and taken as $3.85 \mathrm{~kJ} / \mathrm{kg} \mathrm{K}$.

(l) The pasteurization temperature of the milk is assumed as $76^{\circ} \mathrm{C}$.

(m) The condenser, the evaporator and the absorber temperatures are assumed to be $30^{\circ} \mathrm{C}, 2^{\circ} \mathrm{C}$ and $30^{\circ} \mathrm{C}$, respectively.

(n) The geothermal resource pressure is considered as same with the generator pressure.

(o) The pressure of the chilled water is assumed as atmospheric pressure.

(p) The reference temperature and pressure are taken to be $25^{\circ} \mathrm{C}$ and $101.325 \mathrm{kPa}$, respectively. 
S. Genç

\begin{tabular}{|l|c|c|}
\hline Heat exchanger heat capacity & 17.52 & $\mathrm{~kW}$ \\
\hline Pasteurizer heat capacity & 21.88 & $\mathrm{~kW}$ \\
\hline Regenerator heat capacity & 242.6 & $\mathrm{~kW}$ \\
\hline Cooling section heat capacity & 34.65 & $\mathrm{~kW}$ \\
\hline Pump power & 0.09067 & $\mathrm{~kW}$ \\
\hline COP of the absorption cooling system & 0.5813 & - \\
\hline $\begin{array}{l}\text { Reversible COP of the absorption coo- } \\
\text { ling system }\end{array}$ & 2.275 & - \\
\hline $\begin{array}{l}\text { Thermal efficiency of the whole sys- } \\
\text { tem }\end{array}$ & 71.05 & $\%$ \\
\hline
\end{tabular}

Additionally, exergetic efficiencies of each component in milk pasteurization system were found as between 39\%99\% and the lowest exergetic efficiency belongs to absorber (39.28\%) (Table 2).

Table 2. Exergy loss of the system components.

\begin{tabular}{|l|c|c|c|}
\hline \multicolumn{1}{|c|}{ Component } & $\begin{array}{c}\text { Exergy de- } \\
\text { struction rate } \\
(\mathrm{kW})\end{array}$ & $\begin{array}{c}\text { Exergy } \\
\text { destruction } \\
\text { fraction (\%) }\end{array}$ & $\begin{array}{c}\text { Exergy } \\
\text { efficiency } \\
(\%)\end{array}$ \\
\hline Generator & 0.2501 & 3.587 & 98.82 \\
\hline Condenser & 0.4894 & 7.018 & 57.93 \\
\hline Absorber & 4.577 & 65.63 & 39.28 \\
\hline Heat exchanger & 0.4413 & 6.428 & 97.25 \\
\hline Evaporator & 0.004336 & 0.044 & 99.85 \\
\hline Pump & 0.01011 & 0.153 & 88.85 \\
\hline $\begin{array}{l}\text { Expansion } \\
\text { valve 1 }\end{array}$ & 0.2513 & 3.603 & 93.49 \\
\hline $\begin{array}{l}\text { Expansion } \\
\text { valve 2 }\end{array}$ & 0.9501 & 13.62 & 91.83 \\
\hline $\begin{array}{l}\text { Vapor Absorp- } \\
\text { tion cycle }\end{array}$ & 6.974 & 51.07 & 25.55 \\
\hline Pasteurizer & 0.6739 & 4.935 & 81.87 \\
\hline Regenerator & 5.076 & 37.17 & 64.1 \\
\hline Cooling Section & 0.9323 & 6.827 & 99.85 \\
\hline Whole system & 13.66 & 100 & 56.81 \\
\hline
\end{tabular}

The exergetic efficiency of the whole system was computed as $56.81 \%$. It is planned to optimize the current system in order to improve exergetic efficiency of the whole system through parametric analysis. As seen from the results in Table 2 , the vapor absorption cycle (VAC) has the greatest exergy destruction and its exergetic efficiency is $25.55 \%$. Therefore, in this parametric study, it is firstly focused to VAC system. Totally 6 parameters of the VAC (generator temperature, absorber temperature, condenser temperature, evaporator temperature, heat exchanger efficiency, and geothermal fluid temperature) were chosen for parametric analysis and once a parameter is changed all remaining are set to typical operating conditions. The parametric analysis has started with the generator, which is the first component of the VAC. As it is presented in Figure 2.a, VAC exergetic efficiency reaches to the maximum value $36.34 \%$ when the generator temperature becomes $70^{\circ} \mathrm{C}$ 
and it has very limited effect on the exergetic efficiency of the whole system.

When the generator temperature is taken as $70^{\circ} \mathrm{C}$ and the effect of absorber temperature $\left(25-35^{\circ} \mathrm{C}\right)$ on the exergetic efficiency was studied. It was found that the whole system exergetic efficiency is changed in the range of 56.7-55.3\% by variation in the absorber temperature, whereas any rise in the absorber temperature causes a drop in the exergetic efficiency of VAC. For this reason, the maximum exergetic efficiency of VAC (39.16\%) is calculated when the absorber temperature is $25^{\circ} \mathrm{C}$ (Figure 2.b).

Figure 2. The effect of (a) generator temperature and (b)

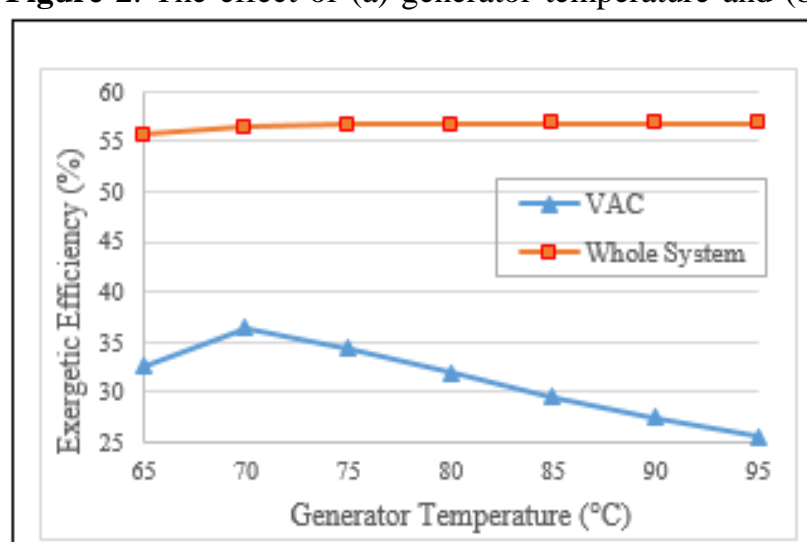

(a)

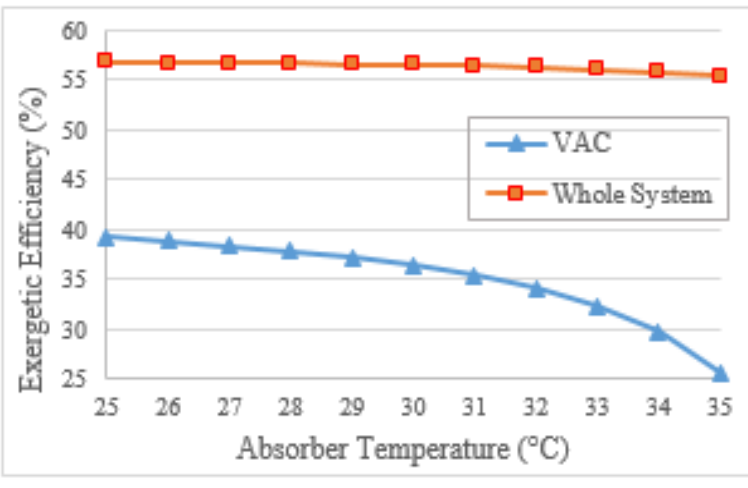

(b)

absorber temperature on the exergetic efficiency.

As the condenser temperature changes between 20 and $35^{\circ} \mathrm{C}$ at the conditions of generator temperature $\left(70^{\circ} \mathrm{C}\right)$ and absorber temperature $\left(25^{\circ} \mathrm{C}\right)$, where the maximum exergetic efficiency was obtained in the VAC, no significant effect on the whole system exergetic efficiency was observed. The exergetic efficiency was $41.55 \%$ at $20^{\circ} \mathrm{C}$ and it decreased to $36.14 \%$ at $35^{\circ} \mathrm{C}$ (Figure 3.a).

Figure 3.b presents the effect of the evaporator temperature on the exergetic efficiency between $-5^{\circ} \mathrm{C}$ and $5^{\circ} \mathrm{C}$. VAC reaches to maximum exergetic efficiency (51.22\%) when evaporator is operated at $-5^{\circ} \mathrm{C}$.

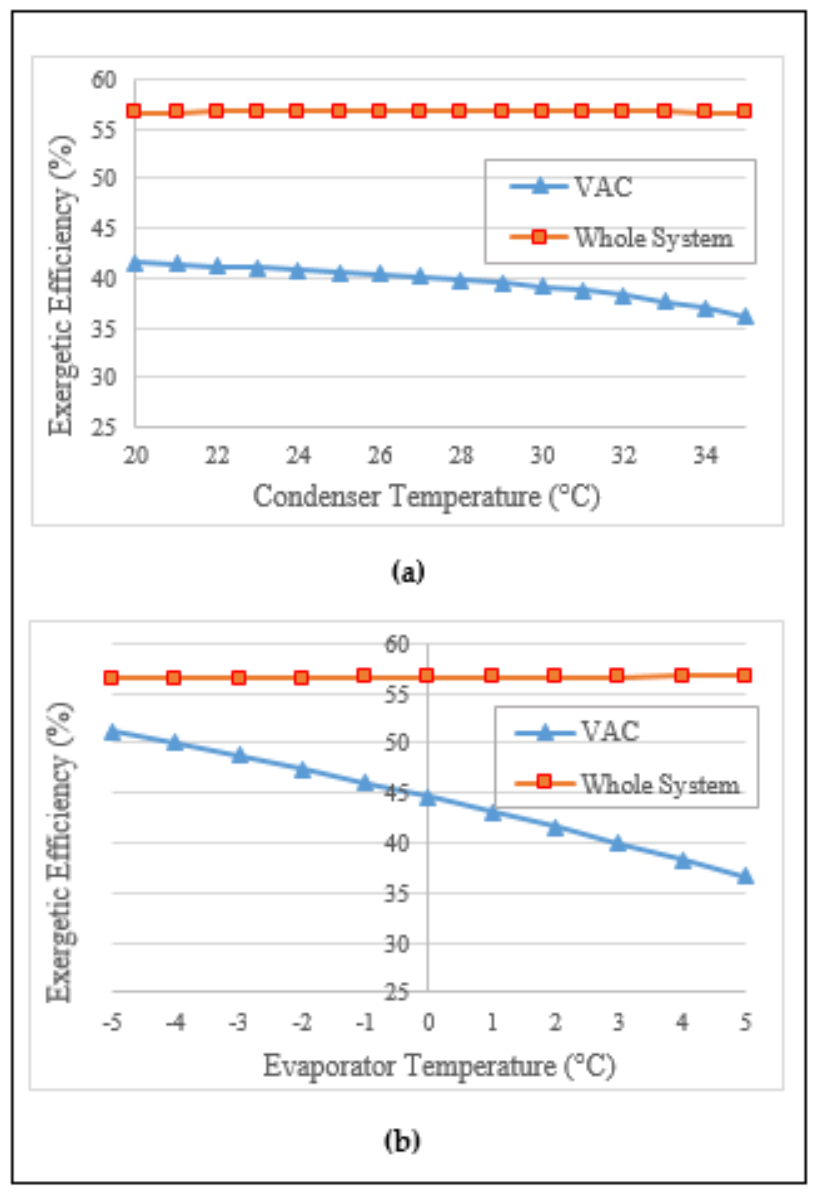

Figure 3. The effect of (a) condenser temperature and (b) evaporator temperature on the exergetic efficiency.

The operating efficiency effect of the heat exchanger on the total exergetic efficiency is examined after the temperatures of generator absorber, condenser and evaporator in the VAC are optimized. As it is seen in Figure 4, the heat exchanger brings the exergetic efficiency from $48.78 \%$ (operating at $70 \%$ efficiency) to $53.91 \%$ when it operates with $90 \%$ efficiency.

Lastly, the effect of the geothermal fluid temperature on the exergetic efficiency is examined. It is found that low geothermal fluid temperatures do not effect on VAC exergetic efficiency whereas they increase the whole system exergetic efficiency. Since exergy efficiency of VAC is directly related to generator temperature, the change in geothermal fluid temperature does not affect VAC's exergy efficiency. 


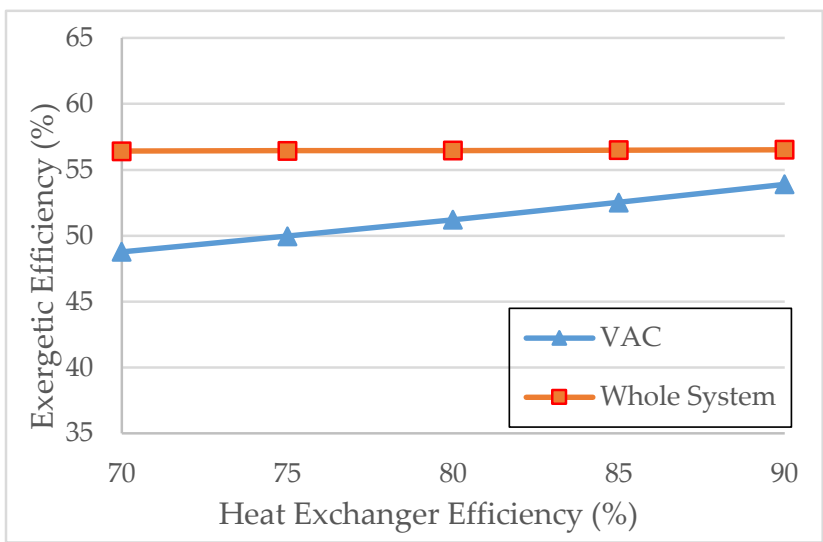

Figure 4. The effect of evaporator temperature on the exergetic efficiency.

At typical operating conditions $\left(\mathrm{T} 16=100^{\circ} \mathrm{C}\right)$ whole system exergetic efficiency is found $56.81 \%$ and it increases to $80.61 \%$ as the geothermal fluid temperature decreases to $85^{\circ} \mathrm{C}$. The reason behind that is, this system is assisted by geothermal fluid as an energy source and the most effective parameter on exergy efficiency is geothermal fluid temperature. Because, exergetic efficiency is defined as the ratio of exergy of product (output) to exergy of fuel (input). The closer the geothermal fluid temperature (input) is to the system conditions, the higher the exergy efficiency. Hence, the required temperature for milk pasteurization $\left(76^{\circ} \mathrm{C}\right)$ could be obtained effectively from a geothermal fluid at $85^{\circ} \mathrm{C}$.

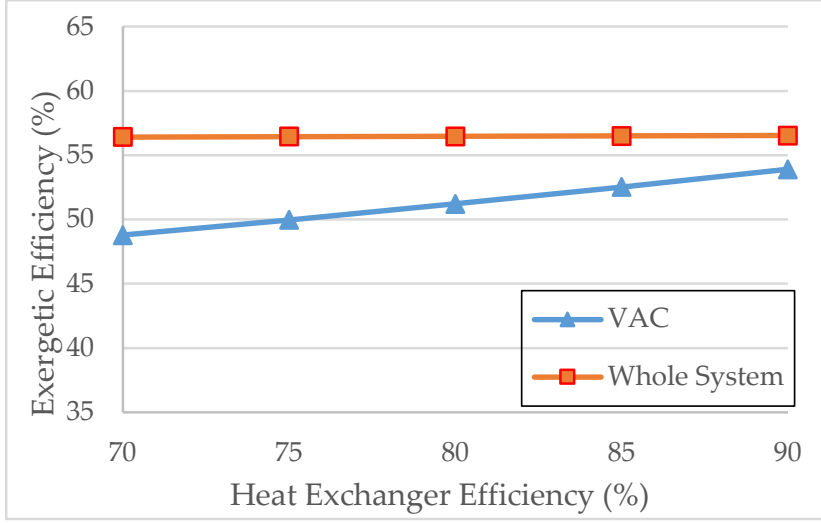

Figure 5. The effect of heat exchanger temperature on the exergetic efficiency.

This study is the first study done for the thermodynamic optimization of a geothermal assisted milk pasteurization system. As there are no similar studies related to thermodynamic optimization in milk pasteurization system, the comparison was made only among the components. In this regard, Aman et al. [10] determined the exergetic efficiency as $32 \%$ in ammonia-water mixture VAC. In another study, the exergetic efficiencies were calculated in two different systems, where different energy resources were used. In the first system, natural gas and electricity was used as energy carrier and the exergetic efficiency was found $10.3 \%$. The energy resources were natural gas and sun in the second system and the exergetic efficiency was changing between $5.2-14.3 \%$ due to sun energy usage ratio [6]. The specific exergy destruction of UHT milk was found as $345.50 \mathrm{~kJ} / \mathrm{kg}$ in a performance assessment of an extended shelf life milk producing facility [7].

\section{Conclusions}

In this research, thermodynamic optimization of milk pasteurization system assisted by geothermal energy was carried out. The thermodynamic analysis of milk pasteurization process assisted by geothermal energy was presented in the previous study of the authors and VAC was found having a highest portion (51.07\%) of exergy destruction [8]. At typical operating conditions the total exergy destruction of the system was calculated as $13.66 \mathrm{~kW}$ and the greatest exergy destruction was due to absorption cooling unit $(6.974 \mathrm{~kW})$. The universal exergetic efficiency of the whole system was computed $56.81 \%$. In order to increase the exergetic efficiency of the system a thermodynamic optimization was applied to 5 parameters of VAC (generator temperature, absorber temperature, condenser temperature, evaporator temperature, heat exchanger efficiency) and geothermal fluid temperature. It was determined the effects of those parameters to the exergetic efficiencies of VAC and the whole system. According those results the optimum operating conditions of a VAC for pasteurization of the milk in the flow rate of $1 \mathrm{~kg} / \mathrm{s}$ were found as $\mathrm{T}_{\text {gen }}=70^{\circ} \mathrm{C}$, $\mathrm{T}_{\text {abs }}=25^{\circ} \mathrm{C}, \mathrm{T}_{\text {con }}=20^{\circ} \mathrm{C}, \mathrm{T}_{\text {evap }}=-5^{\circ} \mathrm{C}$ at $100^{\circ} \mathrm{C}$ geothermal fluid temperature. VAC reaches to maximum exergetic efficieny (53.91\%) when the efficiency of the heat exchanger becomes $90 \%$. Additionally by dropping the temperature of geothermal fluid to $85^{\circ} \mathrm{C}$ just after providing all of the conditions the system exergetic efficiency rises to $80.61 \%$ and this amount could be named as the maximum exergetic efficiency value among the previous researches published in the open literature. In conclusion, in order to design an optimum system, it is very critical to choose of the operating temperatures and efficiencies of the VAC components. It is considered that this study could be supportive to further researches in process design and optimization in dairy and/or other food process where absorption cooling systems are applied. As a further study, it is planned to conduct an economic analysis for selection of the components in regard to accurate assessment of the whole system.

\section{Acknowlegement}

The authors would like to thank Dr.Eray Bozkurt for editing the manuscript.

\section{Symbols \\ COP coefficient of performance (-) \\ $\dot{E} \quad$ energy rate $(\mathrm{kW})$}




$\begin{array}{cl}\text { e } & \text { specific exergy }(\mathrm{kJ} / \mathrm{kg}) \\ \dot{E} x & \text { exergy rate }(\mathrm{kW}) \\ \mathrm{h} & \text { specific enthalpy }(\mathrm{kJ} / \mathrm{kg}) \\ \dot{m} & \text { mass flow rate }(\mathrm{kg} / \mathrm{s}) \\ \dot{Q} & \text { heat transfer rate }(\mathrm{kW}) \\ T & \text { temperature }\left(\mathrm{K} \text { or }{ }^{\circ} \mathrm{C}\right) \\ \dot{W} & \text { rate of work or power }(\mathrm{kW}) \\ \text { VAC } & \text { vapor absorption cycle } \\ \mathcal{E} & \text { exergetic (the second law) efficiency }(-) \\ \text { Subscripts } & \\ \mathrm{D} & \text { destruction } \\ \text { abs } & \text { absorber } \\ \text { con } & \text { condenser } \\ \text { evap } & \text { evaporator } \\ \text { gen } & \text { generator } \\ \text { hex } & \text { hexheat exchanger } \\ \mathrm{u} & \text { universal } \\ \text { in } & \text { input, inlet } \\ \mathrm{k} & \text { location } \\ \text { out } & \text { output } \\ 0 & \text { reference environment }\end{array}$

\section{References}

1. Food and Agriculture Organization of the United Nations. URL:http://www.fao.org/agriculture/dairyegateway/milk-and-milkproducts/en/, (accessed 03.05.2015).
2. Sectoral Milk Statistics in the World and Turkey. National Milk Council of Turkey. (Dünya ve Türkiye'de Süt Sektör İstatistikleri, Ulusal Süt Konseyi). URL:http://www.ulusalsutkonseyi.org.tr/media/81201 4_05_22_905419.pdf, (accessed 03.05.2016).

3. Yildirim Ozcan, N, Gokcen, G, Thermodynamic assessment of gas removal systems for single-flash geothermal power plants, Applied Thermal Engineering, 2009, 29, 3246-3253.

4. Yildirim Ozcan N, Toksoy, M, Gokcen, G, Piping network design of geothermal district heating systems: Case study for a university campus, Energy, 2010, 35, 3256-3262.

5. Szargut, J, Morris, D.R, Steward, F.R, Exergy analysis of thermal, chemical, and metallurgical processes, Hemisphere Publishing Corporation, New York, 1988; pp 215

6. Quijera, J.A, Labidi, J, Pinch and exergy based thermosolar integration in a dairy process, Applied Thermal Engineering, 2013, 50, 464-474.

7. Soufiyan, M.M, Aghbashlo, M, Mobli, H, Exergetic performance assessment of a long-life milk processing plant: a comprehensive survey, Journal of Cleaner Production, 2016, 140(2), 590-607.

8. Yildirim, N, Genc, S, Thermodynamic analysis of a milk pasteurization process assisted by geothermal energy, Energy, 2015, 90, 987-996.

9. F-Chart Software, http://www.fchart.com/, 2014

10. Aman, J, Ting, DS-K, Henshaw, P, Residential solar air conditioning: energy and exergy analyses of an ammonia-water absorption cooling system, Applied Thermal Engineering, 2014, 62, 424-432. 